\title{
THE RELATIONSHIP OF SERUM THYROXINE LEVEL TO BODY MASS OF PIGLETS DURING THEIR POSTNATAL DEVELOPMENT
}

\author{
M. DVOŘ́Á, M. NEUMANNOVÁ and J. BURSA
}

Veterinary Research Institute, 62132 Brno

Received January 29, 1985

\begin{abstract}
Dvớák M., M. Neumannová and J. Bursa: The Relationship of Serum Thyroxine Level to Body Mass of Piglets during Their Postnatal Development. Acta vet., Brno, 55, 1986: 11-21.

Total thyroxine $\left(T_{4}\right)$ levels were determined repeatedly in piglets from birth to 74 days of age in five experiments using 115 piglets from 13 litters divided into groups of heavier and lighter animals according to their body mass at weaning at 21 or 28 days of age and, in one of the experiments, into a group of normally growing piglets and a group of piglets with retarded growth in consequence of sideropoenic anaemia. The thyroxinaemia of newborn piglets was twice that found in adult pigs and continued at a high level, with some variation, throughout the suckling period. By 3 weeks after weaning it had decreased but still exceeded that found in 6-month-old feeder pigs. The decrease was small in piglets with good growth performance after weaning. In groups of newborn piglets, older piglets and feeder pigs of lighter body mass, $T_{4}$ concentration values were generally lower than in their heavier counterparts of equal ages, although the differences did not reach significance. It is suggested that the decisive criterion of body growth in assessing its direct relationship to $T_{4}$ level is relative gain in body mass, a parameter presumably corresponding to the level of nutrition. Low thyroxinaemia was found in piglets with poor or no body mass gain in the last days. This hypothyreous state seems to be a secondary phenomenon and may be transient.
\end{abstract}

Thyroid gland, hormones, body growth, nutrition, anaemia of piglets, swine.

Endocrine glands involved in body growth regulation, interactions between nutrition and hormones as well as hormone control of protein genesis have been recently receiving increased attention also in relation to animal production (Dauzier 1980; Galbraith and Topps 1981; Trenkle and Marple 1983; Buttery 1983). The investigations to date have indicated the complexity of the problem and yielded conflicting results for individual animal species.

An important role among endocrine regulators is played by hormones of the thyroid gland. Thyroxine $\left(\mathrm{T}_{4}\right)$ and triiodothyronine $\left(\mathrm{T}_{3}\right)$ are generally regarded as essential for normal growth, its differentiation in organisms and for maturation of the skeleton. Their numerous control effects affect metabolism, particularly energy metabolism and calorigenesis. The variety of effects observed at different levels of these hormones and the relatively long latent period before their consequences become apparent make it difficult to understand the mechanisms involved in their action and to distinguish the effects conditioned directly by their presence from those bringing other regulators into operation, e.g. growth hormone (Menezes-Ferreira and Torresani 1983). In young rats, growth hormone is more effective in promoting the growth of body mass than that of the skeleton, whereas with $T_{4}$ the reverse is the case. The two hormones act synergistically in bringing the growth of hypophysectomized infant rats back to normal (Glasscock and Nicoll 1981). Experiments on rat fetuses using ligation of the maternal uterine blood vessels demonstrated a positive correlation between body mass and $\mathrm{T}_{4}$ level (Wrutniak and Cabello 1983).

In pigs the thyroid gland has been receiving attention for some time, generally for reasons other 
than diagnosis of their primary diseases. A number of studies have been limited to the morphology of the gland. Direct determination of total $\mathrm{T}_{4}$ in the blood by radioimmunoassay (RIA) has permitted rapid basic examination of thyroid function. Combined with laboratory assessment of other parameters, it has replaced previous diagnostic in vivo tests based on administration of labelled iodine. Published data on $\mathrm{T}_{4}$ levels have shown considerable differences between feeder pigs and adult pigs: 70 to $99 \mathrm{nmol} .1^{-1}$ in pigs of $25 \mathrm{~kg}$ (Linnutaja et al. 1974), $25 \mathrm{nmol} .1^{-1}$ in pigs of $42 \mathrm{~kg}$ in body mass (Sim on et al. 1982) and $54 \mathrm{nmol.1^{-1 }}$ in lactating primiparous sows (Raszyk et al. 1984). The data reported for piglets have been generally higher (Parker et al. 1980a; Kasser et al. 1981, 1982; Ślebodziński et al. 1981; Ślebodziński and Cogiel 1983), the highest value of $141 \mathrm{nmol} .1^{-1}$ being recorded for piglets farrowed on the 108th day of gestation (Parker et al. 1980b).

The finding in pigs that free thyroxine levels were highest 6 to 12 hours after birth along with the observations on metabolic response to thyroxine injection and other evidence led to a conclusion that $\mathbf{T}_{4}$ was an important hormonal factor responsible for metabolic adaptation of the pig to extra-uterine life (Śle bodziński 1979).

Considerable attention has been paid to the development of thyroid function in neonatal pigs, particularly with regard to their survival in the first days after birth depending on sufficient thermogenesis (Parker et al. 1980b, Campion et al. 1981; Fentener van Vlissingen et al. 1983). Only few data, however, are available on blood serum $\mathrm{T}_{4}$ concentration in older piglets. Not even - a study on $\mathrm{T}_{4}$ changes during the postnatal development of the pig (Ślebodziński et al. 1981) included animals over 21 days of age. No data have been published on iodothyronine levels in the blood of piglets during the weaning period which represents a critical period in their life. And it is early weaning in particular that may have a major effect on $T_{4}$ level as was demonstrated in rats (Strbák et al. 1983). To our knowledge, the relationship of the thyroid gland to the growth of pigs has been the subject of only one report covering animals from 10 to 26 weeks of age (Marple et al. 1981).

To elucidate the role of circulating $T_{4}$ in the growth of piglets, a longitudal study on their $T_{4}$ concentration from birth to maturity is required. The present paper reports and compares results obtained at various stages of development in piglets divided according to their body mass into groups of heavier and lighter animals and in feeder pigs of slaughter body mass.

\section{Materials and Methods}

A total of 115 Large White full-term piglets from 13 litters farrowed and reared in the Veterinary Research Institute, Brno, during a two-year period were used for repeated determination of total $\mathrm{T}_{4}$ blood serum levels. During the suckling period they had access to a creeping area with an infra-red lamp, and had water and prestarter available from the 2 nd week after birth. Unless stated otherwise, they were treated preventively against anaemia by i.m. administration of iron-dextran complex in the first week after birth. After being weaned at ages specified in Results, they were moved into straw-bedded pens where a commercial powder-form starter (COS 2) and water were constantly available ad libitum. Moreover, single examinations for total $T_{4}$ blood serum levels were carried out in 35 slaughter pigs, 16 boars of various breeds and 42 breeding gilts and sows from several agricultural enterprises.

Experiment 1 was designed to assess the effects of differing fetal growth in 31 piglets examined within 2 hours of birth before ingestion of colostrum.

Experiment 2 included 59 piglets from 6 litters weaned at an average of 28 days after birth. Half of them were examined at birth ( 0 day), the other half at two days of age and all of them were examined at 14, 28 and 49 days of age. They were divided into two groups according to their body mass at weaning, thus forming a group of lighter body mass piglets (having less than $7.0 \mathrm{~kg}$ at weaning) and a group of heavier piglets $(28$ animals $)$. Included in the results were also those piglets that died before weaning. Besides the 59 piglets used in this experiment, 35 feeder pigs of slaughter body mass, 16 boars and 42 gilts or sows were examined for the sake of comparison.

Experiment 3 comprised 28 piglets from 3 litters weaned early at an average of 21 days after birth and examined as in Experiment 2 except that examinations at and after weaning were carried out one week earlier. On the basis of their weaning body mass, 24 piglets were divided into a group of lighter $(3.7$ to $6.9 \mathrm{~kg}$ ) body mass and a group of heavier $(5.3$ to $7.8 \mathrm{~kg})$ body mass animals, with each litter being represented in the two groups by equal numbers of litter-mates.

Experiment 4 comprised 28 piglets from 4 litters weaned at an average of 32 days after birth. They were used to assess the effects of sideropoenic anaemia. Half of them were treated between 2 and 5 days of age to prevent iron deficiency and the other half were left untreated. The two groups were compared at time points shown in Fig. 4.

Experiment 5 was designed to analyse the situation in piglets showing markedly below-average 
body mass during their postnatal development. Included in this experiment were 14 piglets from litters used in Experiments 2, 3 and 4.

All treatments, blood collections from the cranial vena cava and weighing of the animals were carried out between 8 and 9 hours a.m. without previous food deprivation. Relative body mass gain was computed according to the formula

$$
\mathrm{q}=\frac{\mathrm{y}_{2}-\mathrm{y}_{1} \cdot 100}{\mathrm{y}_{1}}
$$

where $y_{1}$ is initial body mass and

$\mathrm{y}_{2}$ is body mass at a given age.

None of the animals included in the experiments showed any signs of infectious or parasitic disease.

Total thyroxine $\left(\mathrm{T}_{4}\right)$ concentration was determined in triplicate in blood sera stored at $-20^{\circ} \mathrm{C}$ using RIA kits produced by the Institute of Radioecology and Application of Nuclear Technique, Košice, Czechoslovakia. Haemoglobin in the blood of piglets in Experiment 4 was determined by the haemoglobin cyanide method (Homolka 1969). The results are presented as arithmetic means \pm standard errors. The significance of the differences of the means was assessed by Student's t-test.

\section{Results}

In Experiment 1, the body mass of newborn piglets before ingestion of colostrum ranged from 0.5 to $1.7 \mathrm{~kg}$ and their $\mathrm{T}_{4}$ level varied from 73 to $195 \mathrm{nmol}^{-1}$ (Fig. 1). In the group of 14 lighter neonatal body mass piglets of $0.950 \pm 0.046 \mathrm{~kg}(0.5$ to $1.20 \mathrm{~kg}$ ) the $\mathrm{T}_{4}$ concentration was $134.3 \pm 11.2 \mathrm{nmol} . \mathrm{1}^{-1}$. In the group of 17 heavier neonatal body mass piglets of $1.480 \pm 0.041 \mathrm{~kg}(1.25$ to $1.70 \mathrm{~kg})$ the $T_{4}$ concentration was $142.8 \pm 7.8 \mathrm{nmol} .1^{-1}$. The difference in $\mathrm{T}_{4}$ level between the two groups was not significant. Examination of the same piglets 14 days later showed that the initially low $\mathrm{T}_{4}$ levels had increased, occasionally exceeding those found in the animals with initially high $\mathrm{T}_{4}$ levels. It became apparent that enhanced thyroxinaemia may have a beneficial effect on subsequent body growth: when 22 healthy piglets reaching 4 weeks of age were divided into a group of 11 animals of low neonatal $\mathrm{T}_{4}$ level $\left(117.2 \mathrm{nmol} .1^{-1}\right)$ and a group of 11 animals of high neonatal $\mathrm{T}_{4}$ level $\left(173.7 \mathrm{nmol} .1^{-1}\right)$, the mean body mass of the first group was $1.23 \mathrm{~kg}$ at birth and $6.85 \mathrm{~kg}$ at 4 weeks of age, which implies a relative body mass increase by $457 \%$; the mean body mass of the second group was 1.17 at birth and $7.08 \mathrm{~kg}$ at 4 weeks of age, which implies a relative body mass increase by $505 \%$.

In Experiment 2 the mean body mass data for the group of significantly $(\mathrm{P}<0.01)$ lighter piglets were $1.39 \pm 0.05 \mathrm{~kg}$ at two days of age, $5.85 \pm 0.19 \mathrm{~kg}$ at weaning and $11.37 \pm 0.41 \mathrm{~kg}$ at 21 days after weaning. The relative body mass gain up to weaning was $319 \%$ and that after weaning was $95 \%$. The mean body mass data for the group of heavier piglets at the same time points as given above were $1.72 \pm$ $\pm 0.05,8.17 \pm 0.19$ and $14.47 \pm 0.65 \mathrm{~kg}$. The relative body mass gain up to weaning was $375 \%$ and that after weaning was $77 \%$. The $\mathrm{T}_{4}$ concentration, which was highest on the first two days after birth, showed a continuous slight decline up to 49 days of age (21 days after weaning) (Fig. 2). It was lower in the group of lighter piglets than in their heavier counterparts at all examinations except in newborn animals. However, the difference was not significant.

In the group of 35 feeder pigs of about 6 months in age and $85.08 \pm 3.00 \mathrm{~kg}$ in body mass the $\mathrm{T}_{4}$ concentration was $80.9 \pm 3.9 \mathrm{nmol} .1^{-1}$, being significantly $(\mathrm{P}<0.05)$ lower than that found in piglets at 3 weeks after weaning. In the heavier feeder pigs $(90.7 \pm 2.7 \mathrm{~kg}) \mathrm{T}_{4}$ concentration was slightly higher (Fig. 2) than in their lighter counterparts $(79.8 \pm 2.2 \mathrm{~kg})$. It showed no significant difference from $\mathrm{T}_{4}$ levels 


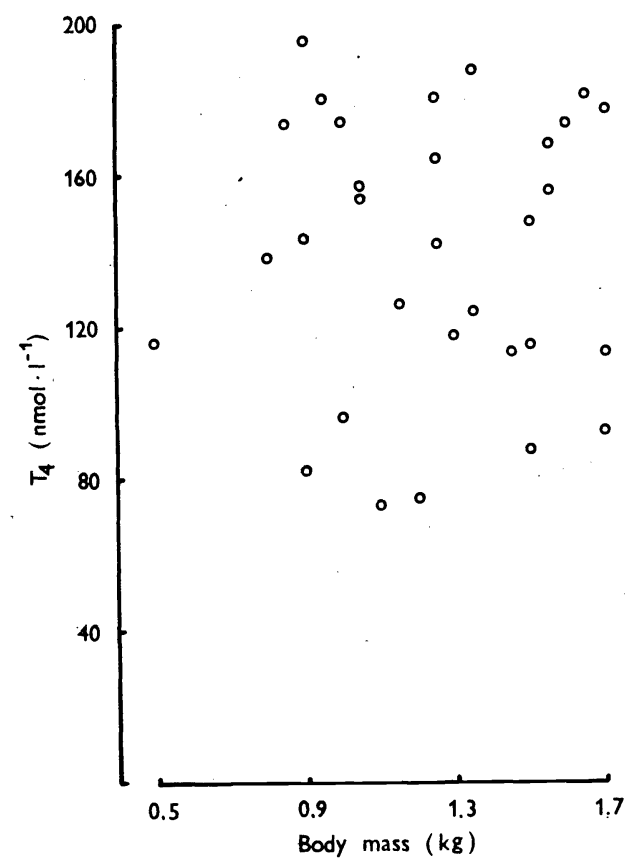

Fig. 1.

Relation of thyroxine $\left(T_{4}\right)$ level to body mass in piglets at birth.

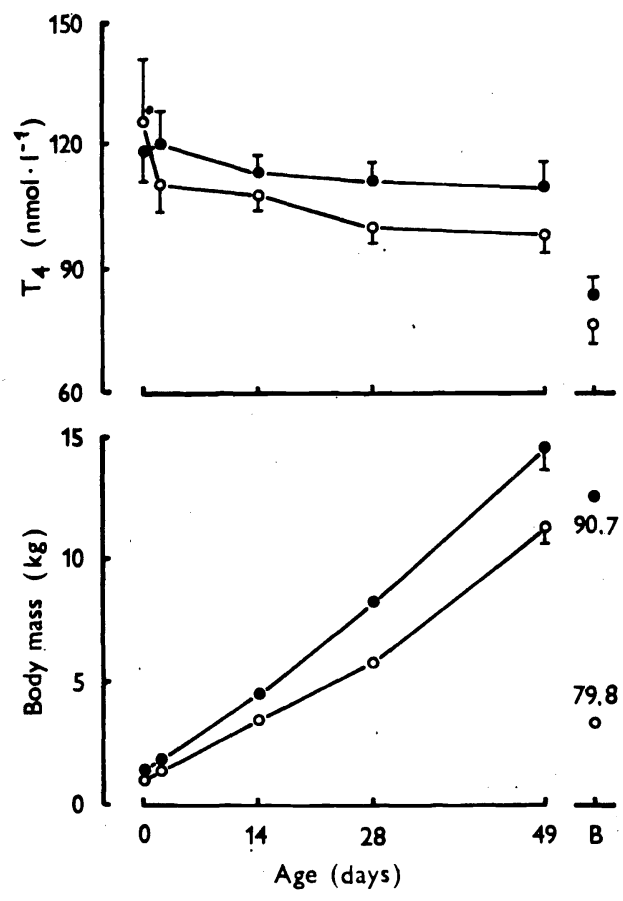

Fig. 2.

Thyroxine $\left(\mathrm{T}_{4}\right)$ levels and body mass of piglets classified as heavier (closed circles) and lighter (open circles) according to their body mass at weaning at 28 days of age as compared with the results obtained for feeder pigs (B).

found in breeding boars $\left(79.6 \pm 6.5 \mathrm{nmol} . \mathrm{1}^{-1}\right)$ and breeding sows and gilts $(67.2 \pm$ $\left.\pm 4.0 \mathrm{nmol} .1^{-1}\right)$.

In Experiment 3 the differences in body mass (Fig. 3) and gain between the lighter and heavier piglets were invariably significant $(P<0.01)$. However, the relative gain from the 2nd day after birth till weaning was slightly larger in the group of lighter piglets $(254 \%$ as against $252 \%$ ), whereas the relative post-weaning gain was equally low (64\%) in both groups. $\mathrm{T}_{4}$ concentration showed no significant differences between the two groups except at birth, at which time 5 heavier piglets had significantly $(P<0.05)$ higher $T_{4}$ values than their 5 lighter littermates (Fig. 3). From day 2 to day 21) weaning day) $T_{4}$ concentration increased non-significantly in both groups, but more so in the lighter piglets. By 21 days after weaning it had shown a significant $(\mathrm{P}<0.01)$ decrease, which was more pronounced in the lighter piglets, and its level corresponded to that found in Experiment 2. Experiment 3 piglets differed from those of the foregoing experiment by being somewhat heavier during the suckling period and showing poor growth performance after weaning.

In Experiment 4 the group of piglets that were not treated with iron-dextran complex after birth developed anaemia with a minimum haemoglobin concentration of $42.7 \pm 3.0 \mathrm{~g} .1^{-1}$. This was manifested by a slow-down in body mass gain between 18 and 60 days of age. The body mass of these piglets between 32 and 53 days of age, 


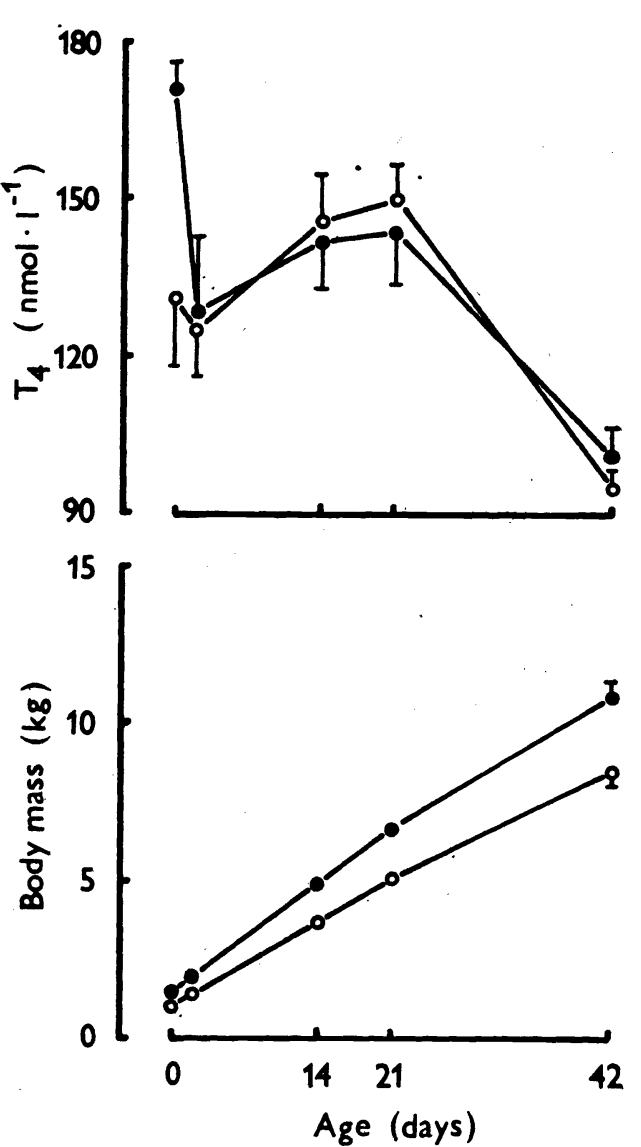

Fig. 3.

Thyroxine $\left(\mathrm{T}_{4}\right)$ levels and body mass of piglets classified as heavier (closed circles) and lighter (open circles) according to their body mass at weaning at 21 days of age.
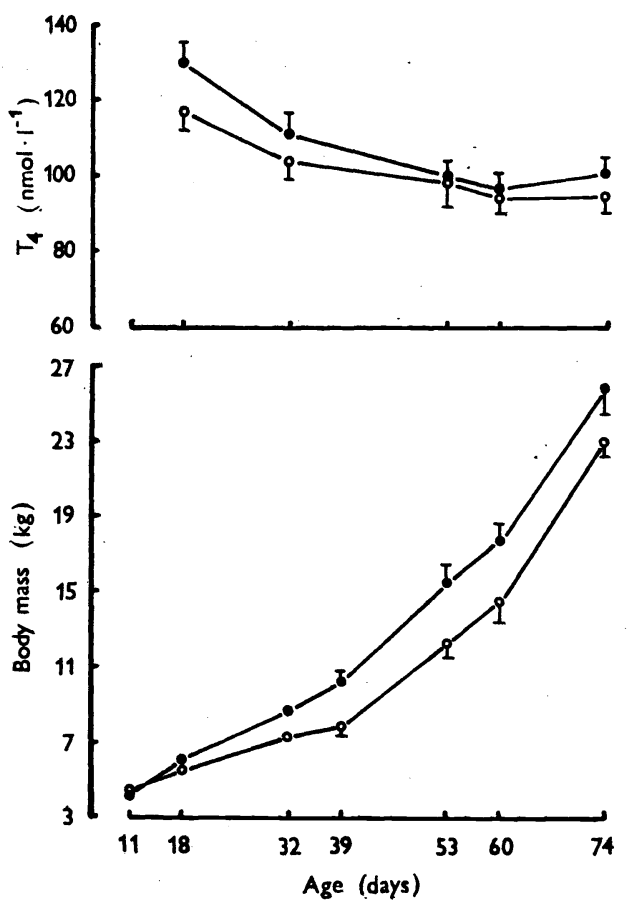

Fig. 4.

Thyroxine $\left(T_{4}\right)$ levels and body mass of anaemic (open circles) and preventively iron-treated (closed circles) piglets weaned at 32 days of age.

when the difference between the groups was $3.5 \mathrm{~kg}$, was significantly. $(\mathrm{P}<0.01)$ lower than that of their preventively treated counterparts. The $T_{4}$ concentration of anaemic piglets was lower than that of their treated and more rapidly growing counterparts throughout the observation period, i.e. from 18 to 74 days of age (Fig. 4). However, not even the largest differences, observed on days 18 and 32, were significant. In both groups the $T_{4}$ concentration showed a continuous downward trend. In anaemic piglets the decrease was significant $(P<0.05)$ between 18 and 60 to 74 days, in healthy animals it became highly significant $(P<0.01)$ as early as 53 days after birth.

Of 14 Experiment 5 piglets showing a markedly below-average body mass during their development, 8 were found to have the lowest $T_{4}$ values $\left(20\right.$ to $\left.80 \mathrm{nmol}^{-1^{-1}}\right)$ recorded in this study. The instances of extremely low $T_{4}$ values were not included in results in the previous experiments. 
At 4 days after birth this applied to 2 piglets of a sow suffering from temporary hypogalactia after farrowing. They weighed 1.6 and $1.4 \mathrm{~kg}$ and their $\mathrm{T}_{4}$ values were 32 and $24 \mathrm{nmol}^{-1} \mathrm{1}^{-1}$, respectively. The first of them died and the other one weighed $2.3,4.3$ and $6.5 \mathrm{~kg}$ and had $\mathrm{T}_{4}$ values of 104,108 and $95 \mathrm{nmol} .1^{-1}$ at 12,24 and 46 days of age, respectively. In 10 piglets of this group the mean body mass at 10 to 15 days of age was $2.67 \mathrm{~kg}$. The low mean $\mathrm{T}_{4}$ level $\left(100.4 \mathrm{nmol} . \mathrm{l}^{-1}\right)$ was due mainly to the findings in 3 piglets with $\mathrm{T}_{4}$ levels of 68,20 and $80 \mathrm{nmol} . \mathrm{1}^{-1}$ and body mass values of $2.8,1.5$ and $2.7 \mathrm{~kg}$, respectively. The first of these animals gained only $1.3 \mathrm{~kg}$ during 12 days, the second - a cachectic one - lost $0.4 \mathrm{~kg}$ during 10 days and died after examination and the third gained $1.05 \mathrm{~kg}$ during 9 days. The remaining animals showed better gains associated with higher $\mathrm{T}_{4}$ levels.

At 21 to 28 days of age ten suckling piglets of the aforementioned group averaged $4.56 \mathrm{~kg}$ in body mass and their mean $\mathrm{T}_{4}$ concentration was $106.9 \mathrm{nmol}^{-1} \mathrm{l}^{-1}$. The lowest $\mathrm{T}_{4}$ concentration $\left(45 \mathrm{nmol} . \mathrm{1}^{-1}\right.$; one week previously: $\left.80 \mathrm{nmol} . \mathrm{l}^{-1}\right)$ was found in a piglet weighing $5 \mathrm{~kg}$ after having lost $0.1 \mathrm{~kg}$ during the preceding 7 days. During the next week this animal lost $0.3 \mathrm{~kg}$ and its $\mathrm{T}_{4}$ concentration decreased to $36 \mathrm{nmol} .1^{-1}$. In another piglet a $\mathrm{T}_{4}$ level of $80 \mathrm{nmol} \cdot 1^{-1}$ rose to $83 \mathrm{nmol} .1^{-1}$ after weaning. On the other hand, the smallest piglet $(3.7 \mathrm{~kg})$ with a weekly gain of $0.6 \mathrm{~kg}$ showed a $\mathrm{T}_{4}$ concentration of $131 \mathrm{nmol}^{-1}$ (143, 174 and $101 \mathrm{nmol} .1^{-1}$ at 0,15 and 43 days, respectively). Among 6 piglets averaging $7.73 \mathrm{~kg}$ in body mass and having a $\mathrm{T}_{4}$ concentration of $89.5 \mathrm{nmol} .1^{-1}$ at 3 weeks after weaning it was the lightest animal $(6.6 \mathrm{~kg})$ with the least gain during the 3 weeks $(2.4 \mathrm{~kg})$ that showed the lowest $\mathrm{T}_{4}$ concentration $\left(73 \mathrm{nmol} .1^{-1}\right)$.

\section{Discussion}

From the results obtained in newborn piglets before ingestion of colostrum it appears that in individual animals neonatal blood serum $T_{4}$ levels may exceed $T_{4}$ values found. at a later age, although half these concentrations are by no means an exception. On the average, neonatal $\mathrm{T}_{4}$ levels in the present study proved the highest of the values recorded at the specified ages, being about twice those obtained in adult pigs. The high individual variability was not due to differences in the somatic development as expressed in terms of body mass at birth. Nevertheless, a trend to higher $\mathrm{T}_{4}$ levels in heavier piglets became apparent. On the other hand, it is not possible to generalize that newborn piglets of less than $1 \mathrm{~kg}$ in body mass are $\mathrm{T}_{4^{-}}$ -deficient.

The possibility cannot be excluded that $T_{4}$ level is affected by a number of factors soon after birth. This appears from published evidence on its changes recorded in piglets at intervals of several hours during the first days after birth. Observations along this line showed a continuous decrease in $\mathrm{T}_{4}$ level up to the $3 \mathrm{rd}$ postnatal day (Parker et al. 1980a). In the first 12 hours this decrease may be more pronounced in a cold environment (Parker et al. 1980b) or more moderate in piglets from fasted sows (Kasser et al. 1982) or, on the contrary, larger when colostrum is withheld (Ślebodziński and Cogiel 1983). Other observations recorded an increase of $\mathrm{T}_{4}$ level up to 24 hours after birth, followed by its decrease by 5 days and another rise peaking generally at 14 days (Śle bodziński et al. 1981). Conflicting data also exist as to $\mathrm{T}_{4}$ levels and the significance of their differences between animals of various ages or individual litters. A solitary observation has been reported on the difference in $T_{4}$ concentration between suckling piglets and adult pigs: the $T_{4}$ level of newborn piglets did not reach double that value recorded for pregnant gilts (Kasser et al. 1982). In newborn calves, on the other hand, the $T_{4}$ level is four to five times higher 
than in cows (Fish and Swanson 1983), its maximum being recorded 2 to 4 hours after birth and its minimum on the 7th postnatal day (Leirer and Deschner 1983).

The $T_{4}$ level changes observed in piglets in Experiments 2 and 3 were not identical. Whereas in Experiment 2 tyroxinaemia showed a slight decrease between 2 and 14 days after birth, it underwent a non-significant increase during the same period in Experiment 3. When Experiment 2 piglets were weaned at 28 days of age, the mean $\mathrm{T}_{4}$ concentration of the heavier ones was $112 \pm 4 \mathrm{nmol} .1^{-1}$, whereas in the heavier Experiment 3 piglets weaned at 21 days of age the mean $T_{4}$ concentration at weaning was $143 \pm 8 \mathrm{nmol} .1^{-1}$. However, 21 days after weaning the mean $T_{4}$ levels of the heavier piglets of both experiments were practically equal: $100 \pm 6$ and $101 \pm 6 \mathrm{nmol}$. $.1^{-1}$. During the suckling period no distinct differences were observed between these piglets from the clinical point of view. All of them were in very good health. The growth rate of Experiment 3 piglets weaned at 21 days of age was slightly better before weaning but substantially worse after weaning, compared with Experiment 2: the total mean gain of the heavier piglets for the first 3 post-weaning weeks was $6.3 \mathrm{~kg}$ in Experiment 2 and only $4.2 \mathrm{~kg}$ in Experiment 3 . The relative gains were $77 \%$ and $64 \%$, respectively. It can be concluded that the abrupt fall of tyroxinaemia after weaning is associated with the poor performance of piglets weaned as early as 21 days after birth. The high $T_{4}$ level at weaning had no beneficial effect on further growth performance and the decrease of $\mathrm{T}_{4}$ concentration was in all likelihood caused by impairment of the nutritional situation after withdrawal of the sows' milk.

The increased $\mathrm{T}_{4}$ level recorded in suckling piglets between 14 and 28 days of age is apparently no exceptional state because it was also found in healthy piglets of Experiment 4. Their relatively good performance after weaning, manifested by large total $(6.9 \mathrm{~kg})$ and relative $(79 \%)$ gain, was also accompanied by a slight decrease of tyroxinaemia from $104 \pm 6$ to $98 \pm 7 \mathrm{nmol}^{-1^{-1}}$ in 3 weeks. Afterwards their $\mathrm{T}_{4}$ level showed little change up to day 74 by which time their mean daily gain had increased to $0.6 \mathrm{~kg}$. An approach to a significantly lower tyroxinaemia in 6-month-old feeder pigs occurs apparently later. That weaning may not be the turning-point in the development of tyroxinaemia from its high level in suckling piglets to its relatively low level in adult pigs appears also from our observations in other piglets (Dvořák et al. 1984) with a large relative body mass gain ( $84 \%$ ) for 3 weeks after weaning at 28 days of age in which $\mathrm{T}_{4}$ concentration decreased during this period by only $1 \mathrm{nmol} .1^{-1}$. The gradual decrease of $\mathrm{T}_{4}$ level during the next period as suggested by the longitudinal observations is reminiscent of the changes reported for humans from the 6th week after birth (Štr bák and Michaličková 1984), but differs from them by the height and course of tyroxinaemia in the first 4 weeks of age.

Suggestive evidence for a direct relationship between body growth and actual tyroxinaemia also appears from comparison of the results obtained in the groups of piglets of lighter and heavier body mass. The former had lower $\mathrm{T}_{4}$ levels in Experiments 2 and 4 where their relative gains in body mass were also lower than those of their heavier counterparts. In Experiment 3, on the other hand, where the relative body mass gain of lighter piglets slightly exceeded that of their heavier counterparts, the $T_{4}$ level of piglets showing less body mass and less actual gain was not invariably lower than in the heavier animals. Therefore relative gain in body mass appears to be the decisive criterion in considering the relationship between tyroxinaemia and body mass in piglets.

Very low $\mathrm{T}_{4}$ concentrations, below physiological levels, which so far are difficult to define in suckling piglets were found in Experiment 5 in animals with arrested growth or body mass losses. Considering that examination of these animals revealed no disease except occasional anaemia it can be assumed that their retarded growth 
was due to nutritional shortcomings of qualitative and particularly quantitative nature. The findings preceding or following the appearance of very low tyroxinaemia suggest that the aforementioned cases can be regarded as a secondary hypothyreous state which may be transient. The condition generally became rectified after the growth performance improved.

It is well established that $\mathrm{T}_{4}$ level may be affected not only by primarily impaired thyroid function but also by a number of factors of internal and external environment (Macho 1975). Besides possible genetically conditioned differences (Ślebodziński and Wallace 1979) it is also the nutritional status which plays a major role in the modulation of thyroid function (Friedman and Zeman 1979; Spencer et al. 1983; Rosa et al. 1983). Also pigs were found to develop a transient decrease of tyroxinaemia under food deprivation (Dvořák et al. 1984) or low nutritional energy intake (Macari et al. 1983). A decrease of $\mathbf{T}_{4}$ level was also recorded in pigs on a protein - restricted diet (Atinmo et. al. 1978)

The low $\mathrm{T}_{4}$ levels observed in groups of piglets and individual animals with reduced growth rate may be a consequence of inadequate nutrition, the spontaneous causes of which are by no means rare during both the suckling period and the weaning period. They may include iron deficiency which was deliberately induced in half of the piglets in Experiment 4 to obtain an anaemic group of reduced body mass; a slow-down of body growth occurs when haemoglobin level falls below $57 \mathrm{~g} .1^{-1}$ between 2 and 4 weeks of age (Dvořák 1964). From the growth rate curves in the present study it can be seen that the groups of piglets with the lighter body mass at weaning in Experiments 2 and 3 showed lower body mass values as early as the 2nd day after birth. In Experiment 4, on the other hand, the growth of anaemic piglets -did not slow down until between 11 and 18 days of age. Although on day 18 the difference in body mass between the anaemic group and the control group was the least, the difference in $T_{4}$ level between the two groups at this day was the largest. A possible explanation is that the onset of iron deficiency in piglets receiving no preventive treatment against anaemia occurs as early as the first postnatal week, whereas its effects on growth performance make themselves felt later. Whether sideropoenia has a direct effect on thyroid function or whether further processes associated with poor growth performance are involved is still an open question. Suggestive evidence in support of the first alternative may be seen in our finding in a previous study of a considerable rise of tyroxinaemia as early as 7 days after treatment of anaemic piglets with iron-dextran complex was started (Dvořák et al. 1984).

It can be regarded as confirmed that certain types of malnutrition leading to decreased growth rate induce, or at least contribute to, a decrease in circulating $\mathrm{T}_{4}$ level. There is no evidence to suggest the opposite. Also the trend to lower tyroxinaemia in newborn piglets of lighter body mass can be accounted for, at least to some extent, by limited nutrition resulting from a certain placental insufficiency. The observations that ligation of the uterine blood vessels in rats reduces fetal body mass more than neonatal $\mathrm{T}_{4}$ level (Wrutniak and Cabello 1983) and that an intact hypothalamus-pituitary axis is not decisive for the growth and development of skeletal muscle in fetal pigs (Campion et al. 1981) are not at variance with the aforementioned interpretation.

It is beyond dispute that thyroid hormones are essential for growth. In piglets, however, their higher or lower blood level under the euthyreous state may not be manifested by corresponding differences in body mass. The role of $T_{4}$ expressed in terms of its circulating level, appears to be permissive rather than decisive. Presumably $\mathrm{T}_{4}$ level varies to a considerable extent in dependence on the capacity and pos- 
sibilities of body growth. It is not surprising that its highest value during the development of pig occurs in the youngest piglets which can double their body mass in a few days. It appears likely that growth stage and dietary protein level affect the effects of thyroid function on growth and protein metabolism not only in young mice (Hayashi et al. 1984), in which the growth-promoting effect of exogenous thyroxine is accompanied by increased body mass gain only under increased protein intake, but also in pigs. The relation of the thyroid gland to body growth depends, no doubt, on numerous circumstances among which nutrition is only one of environmental factors exerting their effects under undisturbed conditions of other endocrine glands.

\section{Vztah sérové hladiny tyroxinu $k$ tělesné hmotnosti během vývoje selat}

U 115 selat 13 vrhů, rozdělených na skupiny s tělesnou hmotností při odstavu 21. nebo 28. den stáŕí větší nebo menší, případně na skupiny s růstem normálním nebo redukovaným $\mathrm{v}$ dủsledku sideropénické anémie, byla stanovena opakovaně od narození do stáŕí až 74 dní hladina celkového tyroxinu $\left(T_{4}\right)$ v krevním séru. Ve srovnání $\mathrm{s}$ dospělými prasaty byla tyroxinémie $\mathrm{u}$ novorozených dvojnásobně vysoká a při nekonstantním kolísání se v údobí sání zvýšená úroveň udržela. Za 3 týdny po odstavu byla snížená, stále však vyšší než u pủlročních běhounů. U selat dobře po odstavu prospívajících bylo snižení malé. U skupin novorozených a starších selat $\mathrm{i}$ běhounů $\mathrm{s}$ menší tělesnou hmotností byla hladina $T_{4}$ většinou nižší než $u$ stejně starých skupin zvířat těžších, rozdíly však nedosáhly průkaznosti. Jako rozhodující kritérium tělesného růstu se při hodnocení jeho přímého vztahu $\mathrm{k}$ hladině $\mathrm{T}_{4}$ jeví relativní přírůstek tělesné hmotnosti, pravděpodobně shodný s úrovní výživy. Nízká tyroxinémie byla zjištěna $\mathrm{u}$ selat $\mathrm{s}$ malými nebo žádnými př́růstky tělesné hmotnosti v poslední dny. Tento hypotyreózní stav má sekundární charakter a může být přechodný.

\section{Отношение сывороточного уровня тироксина к весу в процессе развития поросят}

У 155 поросят 13 племенных гнезд, разделенных по группам с весом при отсадке на 21 или 28 суток возраста больше или меньше, или по группам с нормальным ростом или редуцированньм по поводу сидеропенической анемии определяли повторно оо дня рождения до возраста 74 суток уровень общего тироксина $\left(\mathrm{T}_{4}\right)$ в кровяной сыворотке. ПТо сравнению со взрослыми поросятами тироксинемия у новорожденных была в два раза больше и при непостоянном колебании в период подсоса повышенный уровень оставался неизменным. Через три недели после отсадки он стал ниже, но все же выше, чем у полугодовалых подсвинков. У хорошо развивающихся после отсадки поросят понижение было незначительно. У групп новорожденных, поросят постарше и подсвинок весом поменьше был уровень $\mathrm{T}_{4}$ в большинстве случаев ниже чем у групп животных весом побольше одинакового возраста, однако разница была незначительной. Решающим критерием роста тела в оценке его прямого отношения к уровню $\mathrm{T}_{4}$ является относительный прирость веса, который по всей вероятности тождественный с уровнем питания. Низкая тироксинемия была установлена у поросят с незнечительным приростом веса или его полным отсутствием в последние дни. Приведенное гипоти- 
реозное состояние носит вторичный характер и может быть лишь временным.

\section{References}

ATINMO, T. - BALDIJAO, C. - POND, W. G. - BARNES, H.: The effect of dietary protein restriction on serum thyroxine levels of pregnant or growing swine. J. Nutr., 108, 1978: 1546 to 1553.

BUTTERY, P. J.: Hormonal control of protein deposition in animals. Proc. Nutr. Soc., 42 1983: $137-148$.

CAMPION, D. R. - HAUSMAN, G. J. - RICHARDSON, R. L.: Skeletal muscle development in the fetal pig after decapitation in utero. Biol. Neonate, 39, 1981: 253-259.

DAUZIER, L.: Growth as affected by general hormonal factors and hormonal balances, and the limitations of such studies. Reprod. Nutr. Dévelop., 20, 1980: 349-375.

DVOŘÁK, M.: Diagnostik des Eisenmangels bei Saugferkeln I. Das rote Blutbild. Wien. tierärztl. Mschr., 51, 1964: 245-259.

DVOŘÁK, M. - NEUMANNOVÁ, M. - BURSA, J.: Vývojové a zátěžové změny hladiny tyroxinu a vztah štítné žlázy $\mathrm{k}$ růstu telat. (Research report.) Brno, Výzkumný ústav veterinárního lékařství $1984,44 \mathrm{p}$.

FISH, R. E. - SWANSON, E. W.: Effects of excessive iodide administered in the dry period on thyroid function and health of dairy cows and their calves in the periparturient period. J. Anim. Sci., 56, 1983: 162-172.

FENTENER VAN VLISSINGEN, J. M. - COLENBRANDER, B. - WENSING, C. J. G.: Morphological development of the thyroid gland and serum $\mathrm{T}_{4}$-concentration in the intact and decapitated pig fetus. J. develop. Physiol., 5, 1983: 361-371.

FRIEDMAN, D. J. - ZEMAN, F. J.: Thyroid, pituitary, and hypothalamic hormone levels in neonatal rat pups following maternal protein deficiency. Proc. Soc. exp. Biol. Med., 161, 1979: $275-279$.

GALBRAITH, H. - TOPPS, J. H.: Effect of hormones on the growth and body composition of animals. Nutr. Abstr. Rev., 51, 1981: $521-540$.

GLASSCOCK, G. F. - NICOLL, CH. S.: Hormonal control of growth in the infant rat. Endocrinology, 109, 1981: 176-184.

HAYASHI, K. - AKIBA, Y. - TOMITA, Y. - MATSUMOTO, T.: The concerted effects of thyroid function and dietary protein on growth and protein metabolism in mice at different growth stages. J. Nutr. Sci. Vitaminol., 30, 1984: 235-244.

HOMOLKA, J.: Klinické biochemické vyšetřovací metody s použitím mikro- a ultramikroanalýzy. Praha, 1969, 440 p.

KASSER, T. R. - GAHAGAN, J. H. - MARTIN, R. J.: Fetal hormones and neonatal survival in response to altered maternal serum glucose and free fatty acid concentrations in pigs. $J$. Anim. Sci., 55, 1982: $1351-1359$.

KASSER, T. R. - MARTIN, R. J. - GAHAGAN, J. H. - WANGSNESS, P. J.: Fasting plasma hormones and metabolites in feral and domestic newborn pigs. J. Anim. Sci., 53, 1981: 420-426.

LEIRER, R. - DESCHNER, F.: Pathophysiologische Untersuchungen zur Schilddrüsenfunktion des Kalbes 2. Mitteilung: Schilddrüsenfunktion beim klinisch gesunden Kalb. Arch. exper. VetMed., 37, 1983: 259-272.

LINNUTAJA, A. - BERGNER, H. - SIMON, O. - HUTH, R.: Untersuchungen zur Fütterung von Rapsextraktionsschrot an monogastrische Tiere. 4. Einfluss von Rapsextraktionsschrot auf die Trijodtyronin-Bindungskapazität des Blutserum und den Gehalt an Serumthyroxin im Vergleich zu anderen biochemischen Parametern des Stoffwechsels bei Schweinen und Ratten. Arch. Tierernährung, 24, 1974: 299-307.

MACARI, M. - DAUNCEY, M. J. - RAMSDEN, D. B. - INGRAM, D. L.: Thyroid hormone metabolism after acclimatization to a warm or cold temperature under conditions of high or low energy intake. J. exper. Physiol., 68, 1983: 709-718.

MACHO, L.: Vývoj funkcie endokrinných žliaz a jeho ovplyvnenie vonkajšími zásahmi. Čs. Fysiol., 24, 1975: 403-419.

MARPLE, D. N. - NACHREINER, R. F. - PRITCHETT, J. F. - KUHLERS, D. L.: The relationship of thyroxine secretion rate to growth of swine. J. Anim. Sci., 52, 1981: 500 to 504 .

MENEZES-FERREIRA, M. M. - TORRESANI, J.: Mécanismes d'action des hormones thyroidiennes au niveau cellulaire. Annls Endocr., 44, 1983: 205-216.

PARKER, R. O. - WILlIAMS, P. E. V. - AHERNE, F. X. - YOUNG, B. A.: Postnatal 
changes in concentrations of serum and urinary thyroxine and 3,3,5-triiodothyronine in the pig. J. Anim. Sci., 51, 1980a: 132-137.

PARKER, R. O. - WILliAMS, P. E. V. - AHERNE, F. X. - YOUNG, B. A.: Serum concentration changes in protein, glucose, urea, thyroxine and triiodothyronine and thermostability of neonatal pigs farrowed at 25 and $10^{\circ} \mathrm{C}$. Can. J. Anim. Sci., 60, 1980b: 503-509.

RASZYK, J. - RUBEŚ, J. - TOULOVÁ, M. - URBANOVÁ, J. - RẢSOVSKÁ, B. - MATOUŠKOVÁ, O. - BURSA, J.: Biochemical changes in sows after eleven or more farrowings. Physiol. bohemoslov., 33, 1983: 81-88.

ROSA, G. de - DELlA CASA, S. - CORSEllo, S. M. - RUFFILli, M. P. - ROSA, E. de - PASARGIKLIAN, E.: Thyroid function in altered nutritional state. Exp. clin. Endocr., 82, 1983: 173-177.

SIMON, O. - BERGNER, H. - MÜNCHMEYER, R.: Studies on the range of tissue protein synthesis in pigs: the effect of thyroid hormones. Br. J. Nutr., 48, 1982: 571-582.

SPENCER, C. A. - LUM, S. M. C. - WILBER, J. F. - KAPTEIN, E. M. - NICOLOFF, J. T.: Dynamics of serum thyrotropin and thyroid hormone changes in fasting. J. clin. Endocr. Metab., 56, 1983: 883-888.

SLEBODZINSKI, A. B.: Metabolic response to thyroxine in the newborn pig. Biol. Neonate, 36, 1979: 198-205.

ŚLEBODZIŃSKI, A. B. - COGIEL, F.: Serum thyroid hormone levels in colostrum deprived piglets and calves. Endocr. exper., 17, 1983: 263-270.

SLEBODZIŃSKI, A. B. - NOWAK, G. - ZAMYSLOWSKA, H.: Sequential observation of changes in thyroxine, triiodothyronine and reverse triiodothyronine during the postnatal adaptation of the pig. Biol. Neonate, 39, 1981: 191-199.

ŚLEBODZIŃSKI, A. B. - WALLACE, A. L. C.: Genetic differences in prolactin, thyrotropin and thyroid hormones response to thyrotropin-releasing hormone in the post-weaned calves. In: Hormones and development, Bratislava 1979, p. 399-406.

ŠTRBÁK, V. - MACHO, L. - ŠKULTÉTYOVÁ, M. - MICHALIČKOVÁ, J. - POHLOVÁ, G.: Thyroid hormones in milk: Physiological approach - a review. Endocr. exper., 17, 1983: $219-235$.

ŠTRBÁK, V. - MICHALIČKOVÁ, J.: Hypothalamic-pituitary-thyroid system during suckling peroid in rat and man. Endocr. exper., 18, 1984: 183-199.

TRENKLE, A. - MARPLE, D. N.: Growth and development of meat animals. J. Anim. Sci., 57, 1983: $273-283$.

WRUTNIAK, CH. - CABELLO, G.: Changes in the concentration of thyroxine in the plasma of rat fetusses during late gestation: influence of ligation of the maternal uterine vein and artery. J. Endocr., 99, 1983: 233-238. 